\title{
The Impact of Human Capital on Financial Performance of Entrepreneurial Firms in Serbia
}

DOI: 10.7595/management.fon.2020.0010

\begin{abstract}
:
Research Question: This paper investigates the impact of human capital on the financial performance within entrepreneurial firms in Serbia. Motivation: In today's knowledge-based economy, human capital, as the main component of intellectual capital, represents one of the primary value drivers. The competitiveness of developed countries is based to a large extent on investments in intellectual capital. In most OECD countries, investments in intellectual capital are growing dramatically and in some cases they reach or even exceed investments in tangible assets. This paper primarily builds upon the results of Pena (2002) and Hormiga et al. (2011) and, as far as the author is aware, it represents one of few studies of that kind in Serbia. Idea: The main idea of the paper is to examine whether human capital influences the financial performance of Serbian entrepreneurial firms. Dependent variables are indicators of financial performance, such as ROA and sales revenue. Independent variables represent various elements of human capital. Data: The sample consists of young Serbian companies from various industries with at least three employees, founded in 2015 whose financial statements were published in 2017. Out of 1,559 such companies, 151 completed the survey and participated in the research. Tools: Factor analysis was used and numerical variables that represent the answers to the questions about human capital were loaded into factors. Those factors as independent variables were used in multiple regression analysis (OLS, FGLS and Ordered probit). Findings: It was found that elements of human capital, such as the interaction of the entrepreneurial team, social skills and tenacity, and knowledge of the entrepreneur have a positive impact on ROA. The interaction of the entrepreneurial team has a positive impact on sales revenue. On the other hand, social skills and tenacity and knowledge of an entrepreneur do not have any impact on sales revenue. Contribution: The paper can help entrepreneurs and company founders, as well as economic and development policy makers to better understand the importance of human capital for improving financial and overall business performance of newly created ventures.
\end{abstract}

Keywords: human capital, intellectual capital, financial performance, entrepreneurial firm, Serbia

JEL Classification: C31, C35, M13, O34

\section{Introduction}

In today's knowledge-based economy, human capital, as the main component of intellectual capital, represents one of the primary value drivers. The competitiveness of developed countries is based to a large extent on investments in intellectual capital. The importance of intellectual capital is emphasised by the fact that in 2015 the share of intangible assets in the market capitalization of S\&P 500 was $84 \%$, which represents an increase by four percentage points in comparison with the period of 10 previous years (Ocean Tomo, 2017). In a large number of OECD countries, investments in intellectual capital are growing strikingly and in some cases they reach or even exceed investments in tangible assets. The rise of global competition, ICTs, new business models, and the growing importance of the service sector are the causes of an increased importance of intellectual capital to companies, industries, and national economies (OECD, 2011, p. 1).

The subject of the paper is the analysis of the impact of human capital on financial performance of entrepreneurial firms in Serbia. Although there are various definitions of entrepreneurial firms, all of those firms are considered to be young and newly founded start-ups. For example, in one of the most prominent studies in this field whose results are published in the Global Entrepreneurship Monitor Global Report (Global 
Entrepreneurship Monitor, 2018. p. 21), businesses that are less than 42 months old are regarded as entrepreneurial firms. In accordance with that and due to the data availability, in this research entrepreneurial firms are defined as young Serbian companies from various industries that were founded in 2015 and that published their financial statements in 2017.

There are various definitions of intellectual capital in the literature. What is common to all of them is that intellectual capital represents a combination of immaterial resources such as knowledge, know-how, skills, data bases, organizational structure, procedures, corporate culture, values, relationships with buyers and suppliers, and firm's reputation. In most definitions it is stated that intellectual capital is a non-monetary asset without physical substance, however, it has value or it can generate future benefits (Choong, 2008, p. 613).

There are also various categorizations of intellectual capital; one that is most widely used in the literature divides intellectual capital into three categories: human capital, structural capital, and relational capital. This classification was made within the project Measuring Intangibles to Understand and Improve Innovation Management - MERITUM (2002). The paper focuses on human capital. Since the subject of this research is entrepreneurial firms, human capital consists of the elements such as the entrepreneur's knowledge, motivation, commitment, tenacity, social skills, and the interaction of the entrepreneurial team.

Financial performance indicators that are used in the research are return on assets (ROA) and sales revenue. Since this research focuses on young companies that were founded in 2015 only accounting performance indicators were used. The performance indicators such as economic value added (EVA) and cash flow return on investments (CFROI) were not used since they require calculation of the cost of equity which is impossible to obtain in this case.

The paper is organized into six sections. Section 1 is an introduction. Section 2 presents the literature review on the topic of intellectual capital and business performance. Section 3 explains research methodology, which includes the development of research hypotheses, identification and description of the variables used in this empirical study. Section 4 describes the sample. Section 5 presents empirical findings. Finally, Section 6 contains concluding remarks, limitations, and recommendations for future research.

\section{Literature Review}

There is a small number of studies about the impact of human capital (and more generally intellectual capital) on the performance of entrepreneurial firms. Pena (2002) analysed the extent to which intellectual capital assets are associated with business start-up success in Spain. The author shows that human capital of the entrepreneur, organizational capital, and relational capital are important intangible assets that are related positively to venture performance. The author points out that entrepreneurs who have a college degree, prior managerial experience and who are highly committed to start a new venture are more likely to create a successful company. Hormiga et al. (2011) analysed the influence of intellectual capital on the success of newly created ventures. The sample consisted of 130 new companies registered in the Canary Islands that were between 3 and 42 months old. The results of this research indicate that human and relational capital play an important role in the development of new companies, while the structural capital is less important. The elements of human capital that are in positive correlation with the success of newly-created firms are the interaction of the entrepreneurial team, entrepreneur's knowledge, resolve and commitment to the firm, while entrepreneur's extrinsic motivation turns out to be negatively correlated with the success of newlycreated firms.

Ramos-Rodriguez et al. (2010) analysed the influence of intellectual and social capital on individuals' ability to recognize new business opportunities in the area of their residence. The study took place in Spain and the results indicated that individuals' access to the external knowledge gained through the social networks is the most important for developing the capacity to recognize good business opportunities. Matricano (2016) investigated the impact of intellectual capital on start-up expectations of aspiring entrepreneurs in Italy during the period of 2005-2010. The results of his study indicate that over the years 2005-2009 human, structural and relational capital affected start-up expectations. In 2010 human and relational capital affected startup expectations, while the results for structural capital were not statistically significant. Khan at al. (2019) analysed whether intellectual capital affects venture creation decisions in India. Their results outline that the components of intellectual capital, such as knowledge, skills and educational level of the entrepreneur, entrepreneurial opportunities, connections with other entrepreneurs and business angels, have a significant and positive impact on venture creation decisions. 
Ugalde-Binda et al. (2014) examined the influence of intellectual capital and personal characteristics of entrepreneurs on innovation results in Costa Rica. Using the case study, the authors concluded that human capital and the characteristics of an entrepreneur have a significant impact on the firms' results. Petrova Galabova (2014) studied whether entrepreneurial firms in Bulgaria recognized and managed their intangible assets. Based on the results of three case studies, the author concludes that entrepreneurial firms that participated in the study recognize their intellectual capital through its three components. Human capital is the most widely acknowledged capital compared to structural and relational capital. Unger et al. (2011) analysed the results of 70 research studies on human capital and entrepreneurial success. The authors concluded that there is a certain, however, significant relationship between human capital and success. Moreover, they found that human capital is most important if it is task-related and if it consists of the outcomes of human capital investments (knowledge and skills) rather than human capital investments (education and experience).

Tovstiga \& Tulugurova (2007) investigated the impact of intellectual capital on enterprise performance in small innovative enterprises in the St Petersburg region in Russia. The results indicate that intellectual capital, particularly structural and human capital, is considered by Russian managers to be a primary determinant of enterprise performance. Zeghal \& Maaloul (2010) analysed the impact of intellectual capital on the firm's economic, financial, and stock market performance. The sample consisted of 300 UK companies divided into three groups of industries: high-tech, traditional, and services. The results of this study reveal that companies' IC has a positive impact on economic and financial performance. The authors also found that capital employed remained a major determinant of financial and stock market performance even though it had a negative impact on economic performance.

As far as the author is aware, there are only few studies about the influence of human capital on the performance of Serbian entrepreneurial firms. Simic \& Slavkovic (2019) examined the relationship between human capital and innovativeness of entrepreneurial firms in Serbia. The sample consisted of 121 entrepreneurs who have started their business in the last five years. Human capital included elements such as entrepreneurs' education, entrepreneurs' previous experience and entrepreneurial self-efficacy. The authors concluded that education and self-efficacy had a positive impact on innovativeness, while the results for entrepreneurs' previous experience were not statistically significant. Simic \& Ognjanovic (2019) analysed the impact of human capital efficiency (HCE) on the performance of new ventures in Serbia. The sample consisted of 29 companies nominated for the "Entrepreneur of the 2016 year" award. The performance measures included net profit, ROA, employee productivity and profitability. The results indicate that HCE has a positive impact on all four performance indicators.

Janosevic \& Dzenopoljac (2012) examined the impact of intellectual capital on the performance of 300 largest Serbian exporters. The results indicate that intellectual capital and its components do not have any influence on the firms' export performance, such as export volume and export volume per employee. However, the authors found a positive relationship between intellectual capital and firms' financial performance. They found that human capital has a positive impact on ROA and employee productivity. Janosevic at al. (2013) analysed the impact of intellectual capital on the financial performance of 100 Serbian companies within the real sector that had achieved the highest profits in 2010. The authors found that human capital had affected ROE and ROA. On the other hand, other measures of financial performance, such as net profit, operating profit and operating revenue were not a consequence of an efficient use of human capital and intellectual capital in general.

Komnenic \& Pokrajcic (2012) analysed the impact of intellectual capital on corporate performance of 37 multinational companies that established their business in Serbia from 2006 to 2008. The results of this study reveal that human capital has a positive impact on ROA, ROE and productivity, while structural capital shows a statistically significant and positive relationship only with ROE. Janosevic \& Dzenopoljac (2015) evaluated the impact of intellectual capital on market and financial performance of companies listed on the Belgrade Stock Exchange during the period of 2010-2014. The sample consisted of 42 companies that made the BELEXline index. According to the research results, human capital, as a component of intellectual capital, positively affects financial and market performance of companies.

Komnenic et al. (2011) analysed the impact of intellectual capital on corporate performance of Serbian banks. The sample included 24 banks which had consistency in producing positive value-added amount during the period of 2005-2008. The authors used ROA, ROE and productivity (asset turnover) as performance indicators. The results point out that human capital has a positive impact on all three performance measures. A similar study, conducted by Bontis et al. (2013), examined the impact of intellectual capital on corporate performance of Serbian banks during the period of 2008-2011. In this study, the sample consisted of 33 commercial banks, which was the total number of banks operating in Serbia during the observed period. The performance measures included profitability, total assets, ROA, ROE, and employee productivity. The results demonstrate that human capital significantly affects only employee productivity. 
Bontis et al. (2015) measured the impact of physical, financial, and intellectual capital on financial performance in Serbian hotel industry. The results of this study reveal that the financial performance of hotels in Serbia remains predominantly influenced by an efficient use of physical capital. Human capital, as a component of intellectual capital, has a positive impact on profitability and a negative impact on employee productivity. Dzenopoljac et al. (2016) explored the impact of intellectual capital on financial performance of Serbian ICT companies. The analysis included 13,989 companies during the period of 2009-2013. The performance measures included ROE, ROA, ROIC, profitability, and asset turnover. The results of the study indicate that intellectual capital does not have a significant effect on financial performance. Human capital had a positive impact regarding ROIC.

Djekic (2015) analysed the level of human capital development in Serbia using the Human Capital Index from Human Capital Report of the World Economic Forum. The results indicate that the human capital in Serbia is at a low level. The author concludes that the improvement of human capital requires a better socioeconomic environment, employment growth as well as a reform of education, health and labour markets.

In many research studies and especially in those that were done on Serbia, the indisputable influence of human capital and intellectual capital in general was not confirmed. One explanation for that is the fact that intellectual capital is not always a critical factor for success and the effects of intellectual capital cannot be achieved automatically (Janosevic \& Dzenopoljac, 2016, p. 191). Bearing that in mind, along with the idea that human capital should be of paramount importance in the first few years of life of newly founded companies, the following two hypotheses were proposed:

$\mathrm{H} 1$ : Entrepreneurial firms that have greater human capital tend to have higher ROA

$\mathrm{H} 2$ : Entrepreneurial firms that have greater human capital tend to have higher sales revenue

\section{Research Methodology}

The data about entrepreneurial firms were obtained through the questionnaire that had been sent to them as well as from their annual financial statements that were publicly available. Research hypotheses were tested through multiple regression analysis in which the dependent variables are the indicators of financial performance, such as ROA and sales revenue. Independent variables represent various elements of human capital, but their exact number was determined after conducting the factor analysis. Besides the independent variables, two control variables were used: the number of employees as the indicator of firm size and the type of industry (manufacturing, trade, services related to manufacturing and other services). In the multiple regression analysis, manufacturing companies were chosen as a base group and dummy variables were created for trade and service companies.

In this research, the companies from the Manufacturing and Construction Sections of Statistical classification of economic activities in the European Community - NACE Rev. 2. (Eurostat, 2008) were classified as manufacturing companies. The companies from the Wholesale and Retail Trade; Repair of Motor Vehicles and Motorcycles Sections were classified as trade companies. Companies from Transportation and Storage, Information and Communication, and Professional, Scientific and Technical activities were classified as companies that provide services related to manufacturing. Finally, the companies from Accommodation and Food Service activities, Administrative and Support Service activities, Financial and Insurance activities, Real Estate activities, Education, Human Health and Social Work activities, Arts, Entertainment and Recreation and other service activities were classified as companies that provide other services.

The data on financial performance indicators were obtained from the companies' annual financial statements for the year 2017. Sales revenue was taken directly from the companies' income statements, while ROA was calculated as the ratio of the company's operating profit to the average value of the company's total assets.

In the literature, return on equity (ROE), which represents the ratio of company's net profit to the average value of equity, is often used as the indicator of financial performance as well. However, in this research ROE was not used because the data necessary for its calculation turned out to be unreliable. A large number of companies in the sample had a negligibly small amount of equity (almost equal to zero). Consequently, a number of companies had low amounts of net profit, yet extremely high values of ROE.

The data on human capital were obtained through the questionnaire in which the respondents received two sets of questions. In the first set of questions, the respondents were asked to assess various statements on a five-point Likert scale (1-strongly disagree, 5-strongly agree). In the second one, the respondents were asked to write a certain number, for example, the length of work experience at the time their company was 
founded. Since the data obtained in this way were not in the standardized form, they had to be converted into the values that range from 1 to 5 so that they could be comparable with the data from Likert scale. The data were standardized using the min-max transformation, which was also used by the World Economic Forum (2017, p. 323).

According to Pena (2002) and Hormiga et al. (2011), human capital is divided into five elements: (1) Knowledge of the entrepreneur, (2) Motivation, (3) Commitment and tenacity, (4) Social skills and (5) Interaction of the entrepreneurial team.

Knowledge of the entrepreneur represents a key resource of a newly founded firm. It can be measured based on the entrepreneur's level of education and prior work experience. In accordance with that and similarly to Pena (2002, p. 184), the questionnaire contains four questions that are designed to measure entrepreneur's knowledge.

Hormiga et al. (2011, p. 75) assert that entrepreneurs who are driven by intrinsic motivation are more successful than those driven by extrinsic motivation. Entrepreneurs driven by intrinsic motivation usually establish their companies to put personal ideas into practice or to be independent and their own bosses. Conversely, the main reason why entrepreneurs driven by extrinsic motivation establish their companies is the impossibility of finding a job. Accordingly, the questionnaire contains three questions with the aim of measuring entrepreneur's intrinsic and extrinsic motivation.

Since processes and routines are rarely developed in new companies, entrepreneurs have to make a greater effort to overcome that deficiency. Because of that, commitment and tenacity of the entrepreneur represent important elements of human capital. Commitment was measured based on the number of hours an entrepreneur spends working in his/her company per week and the percentage of the initial capital invested in the new company and originating from the savings of the entrepreneur. This method for measuring commitment was also used by Pena (2002, p. 197). For measuring entrepreneur's tenacity, two questions were formulated like those proposed by Baum \& Locke (2004, p. 593).

Baron \& Markman (2003) indicate that two social skills, namely social perception and social adaptability, contribute to the success of new companies. They define social perception as the accuracy in perceiving others and social adaptability as the ability to adapt to a wide range of social situations (p. 42). The authors used five questions to measure social perception and five questions to measure social adaptability. Out of those ten questions, four questions were taken and adopted for this research; two questions for measuring social perception and two questions for measuring social adaptability.

Companies are usually created by more than one individual and, for that reason, the interaction within the entrepreneurial team represents an important element of human capital. Lechler (2001, pp. 270-271) indicates that healthy interaction among team members characterized by communication, coordination and cohesion is an important factor of a new venture success. Out of 16 questions used by the author, five questions were taken and adopted for measuring the interaction within the entrepreneurial team.

\section{Sample Description}

In 2015, 8,180 new companies were founded in Serbia, but at the end of 2017, 7,197 companies survived, indicating that survival rate was $88 \%$ (Cokorilo at al., 2018, p. 4). Out of the total number of the companies that survived, 4,966 filed valid financial statements for the year 2017.

The sample consists of young Serbian companies from various industries with at least three employees. The companies were founded in 2015 and their financial statements were published in 2017. There are 1,559 such companies and they are presented in Table 1. The reason why companies with less than three employees were excluded from the sample is that a large number of them had incomplete financial statements. Moreover, many companies with one or two employees had financial statements that seemed inconsistent. For example, some of them reported large operating profit and small (almost equal to zero), yet positive net profit.

The questionnaire was tested prior to being sent to entrepreneurs. The author asked several entrepreneurs to fill in the questionnaire and express their opinion about the questions and the structure of the questionnaire. The final version of the questionnaire was sent via email to the founders/entrepreneurs of the companies that were included in the sample. The author managed to find 1,164 email addresses to which the questionnaire was sent. The email contained a cover letter and the questionnaire in the attachment. There were four reminders along with the process of data collection lasting from December 2018 until April 2019. 
In the end, 198 entrepreneurs completed the survey, which means that the response rate was $17 \%$. Out of 198 questionnaires that were received, 47 had to be excluded from further analysis. First of all, the companies whose owners did not answer a large number of questions were excluded from the research. If an entrepreneur skipped one or two questions, the sample mean values were added instead of the answers. Afterwards, the answers of the entrepreneurs were matched with the companies' financial statements. The companies which reported net loss above the value of their equity were excluded from the sample as well. The final number of companies that participated in the analysis was 151.

Table 1: Companies that took part in the study

\begin{tabular}{|c|c|c|c|c|}
\hline \multirow{2}{*}{ Sectors } & \multicolumn{2}{|c|}{ Total } & \multicolumn{2}{|c|}{ Surveyed } \\
\hline & $\mathbf{N}$ & $\%$ & $\mathbf{N}$ & $\%$ \\
\hline A. Manufacturing & 388 & $25 \%$ & 48 & $32 \%$ \\
\hline 1. Manufacturing & 276 & $18 \%$ & 38 & $25 \%$ \\
\hline 2. Construction & 112 & $7 \%$ & 10 & $7 \%$ \\
\hline B. Trade & 412 & $26 \%$ & 38 & $25 \%$ \\
\hline 1. Wholesale and retail trade & 412 & $26 \%$ & 38 & $25 \%$ \\
\hline C. Services related to manufacturing & 443 & $28 \%$ & 42 & $28 \%$ \\
\hline 1. Transportation and storage & 123 & $8 \%$ & 6 & $4 \%$ \\
\hline 2. Information and communication & 105 & $7 \%$ & 12 & $8 \%$ \\
\hline $\begin{array}{l}\text { 3. Professional, scientific and technical } \\
\text { activities }\end{array}$ & 215 & $14 \%$ & 24 & $16 \%$ \\
\hline D. Other services & 316 & $20 \%$ & 23 & $15 \%$ \\
\hline 1. Accommodation and food service activities & 155 & $10 \%$ & 9 & $6 \%$ \\
\hline 2. Administrative and support service activities & 63 & $4 \%$ & 8 & $5 \%$ \\
\hline 3. Financial and insurance activities & 16 & $1 \%$ & 0 & $0 \%$ \\
\hline 4. Real estate activities & 20 & $1 \%$ & 2 & $1 \%$ \\
\hline 5. Education & 27 & $2 \%$ & 1 & $1 \%$ \\
\hline 6. Human health and social work activities & 10 & $1 \%$ & 1 & $1 \%$ \\
\hline 7. Arts, entertainment and recreation & 13 & $1 \%$ & 0 & $0 \%$ \\
\hline 8. Other service activities & 12 & $1 \%$ & 2 & $1 \%$ \\
\hline Total & 1,559 & $100 \%$ & 151 & $100 \%$ \\
\hline
\end{tabular}

133 micro companies and 18 small companies participated in the research. Most of the companies are from Belgrade (38\%) and Novi Sad (11\%). Table 2 shows the descriptive statistics for the companies included in the sample for the year 2017.

Table 2: Descriptive statistics of the companies included in the sample for the year 2017

\begin{tabular}{|l|c|c|c|c|c|}
\hline & Min & Max & Me & M & SD \\
\hline Sales revenue (in thousands RSD) & 1,587 & 729,880 & 24,593 & 48,113 & 81,657 \\
\hline Operating profit (in thousands RSD) & $-10,817$ & 68,178 & 761 & 3,452 & 9,177 \\
\hline Net profit (in thousands RSD) & $-10,282$ & 54,208 & 470 & 2,612 & 6,834 \\
\hline ROA & $-21 \%$ & $145 \%$ & $11 \%$ & $23 \%$ & $30 \%$ \\
\hline ROE & $-94 \%$ & $531 \%$ & $61 \%$ & $78 \%$ & $78 \%$ \\
\hline Number of employees & 3 & 147 & 6 & 8 & 13 \\
\hline
\end{tabular}

It is obvious that standard deviation and the range (the difference between the highest and the lowest value) are much higher in case of ROE in comparison with ROA. Moreover, the mean and the median of ROE seem to be at unrealistically high level. For all those reasons, ROE could not be used as the indicator of financial performance in this research.

\section{Results and Discussion}

As noted above, the data on human capital were obtained through the questionnaire while the data on financial performance indicators were retrieved from the companies' annual financial statements for the year 2017. After the data on human capital were collected, the answers from the entrepreneurs were transformed 
into numerical variables and a factor analysis was conducted. Numerical variables that represent the answers to the questions regarding human capital were loaded into factors. Those factors represent independent variables used in the multiple regression analysis. A factor analysis was performed using SPSS, while a multiple regression analysis was carried out using STATA.

\subsection{Factor analysis}

The questions regarding human capital were divided into five groups in accordance with the elements of human capital: (1) Knowledge of the entrepreneur, (2) Motivation, (3) Commitment and tenacity, (4) Social skills, and (5) Interaction of the entrepreneurial team. The tables 3-7 show the percentage structure of the answers to the questions in which the respondents were asked to assess various statements on a five-point Likert scale (1-strongly disagree, 5-strongly agree). For the questions in which the respondents were asked to write a certain number, descriptive statistics for the answers was presented.

Table 3: Descriptive statistics and percentage structure of the answers to the questions on entrepreneur's motivation

\begin{tabular}{|c|c|c|c|c|c|c|c|}
\hline \multicolumn{3}{|l|}{ Knowledge of the entrepreneur } & Min & Max & $\mathrm{Me}$ & $M$ & SD \\
\hline \multicolumn{3}{|c|}{$\begin{array}{l}\text { 1. How many years of work experience did you have when you } \\
\text { established your company? }\end{array}$} & 0 & 45 & 10 & 14 & 12 \\
\hline \multicolumn{3}{|c|}{$\begin{array}{l}\text { 2. How many years of work experience in related business activities } \\
\text { did you have when you established your company? }\end{array}$} & 0 & 40 & 5 & 8 & 8 \\
\hline \multicolumn{3}{|c|}{$\begin{array}{l}\text { 3. How many years of work experience in managerial positions did } \\
\text { you have when you established your company? }\end{array}$} & 0 & 30 & 3 & 5 & 6 \\
\hline \multirow{2}{*}{$\begin{array}{l}\text { 4. Estimate the level of your education on a scale } \\
\text { of } 1 \text { to } 5 \text { (1-elementary school degree, 2-high } \\
\text { school degree, 3-college degree, 4-university } \\
\text { degree, } 5 \text {-MSc or PhD degree). }\end{array}$} & 1 & 2 & 3 & 4 & 5 & $M$ & SD \\
\hline & $0.7 \%$ & $31.8 \%$ & $13.9 \%$ & $37.7 \%$ & $15.9 \%$ & 3.36 & 1.11 \\
\hline
\end{tabular}

Table 4: Percentage structure of the answers to the questions on entrepreneur's motivation

\begin{tabular}{|l|c|c|c|c|c|c|c|}
\hline \multicolumn{1}{|c|}{ Motivation } & $\mathbf{1}$ & $\mathbf{2}$ & $\mathbf{3}$ & $\mathbf{4}$ & $\mathbf{5}$ & $\mathbf{M}$ & SD \\
\hline $\begin{array}{l}\text { 1. One of the main reasons why I established a } \\
\text { company is because I was not able to find a good } \\
\text { job. (reverse scoring) }\end{array}$ & $8.1 \%$ & $4.4 \%$ & $21.9 \%$ & $18.8 \%$ & $41.3 \%$ & 3.85 & 1.27 \\
\hline $\begin{array}{l}\text { 2. One of the main reasons why I established a } \\
\text { company is because I wanted to be independent } \\
\text { and my own boss. }\end{array}$ & $9.4 \%$ & $6.9 \%$ & $21.9 \%$ & $22.5 \%$ & $33.8 \%$ & 3.682 & 1.298 \\
\hline $\begin{array}{l}\text { 3. One of the main reasons why I established a } \\
\text { company is because I wanted to put my personal } \\
\text { ideas into practice. }\end{array}$ & $1.9 \%$ & $2.5 \%$ & $15.0 \%$ & $21.9 \%$ & $53.1 \%$ & 4.291 & 0.963 \\
\hline
\end{tabular}

Table 5: Descriptive statistics and percentage structure of the answers to the questions on entrepreneur's commitment and tenacity

\begin{tabular}{|c|c|c|c|c|c|c|c|}
\hline \multicolumn{3}{|l|}{ Commitment } & Min & Max & Me & $M$ & SD \\
\hline \multicolumn{3}{|c|}{$\begin{array}{l}\text { 1. How many hours per week do you work on average in your } \\
\text { company? }\end{array}$} & 3 & 100 & 50 & 45 & 22 \\
\hline \multicolumn{3}{|c|}{$\begin{array}{l}\text { 2. What percentage of the company's initial capital comes from your } \\
\text { personal savings? }\end{array}$} & 0 & 100 & 100 & 74 & 35 \\
\hline Tenacity & 1 & 2 & 3 & 4 & 5 & $M$ & SD \\
\hline $\begin{array}{l}\text { 3. I can think of many times when I persisted with } \\
\text { work when others quit. }\end{array}$ & $0.0 \%$ & $2.5 \%$ & $8.8 \%$ & $35.6 \%$ & $47.5 \%$ & 4.36 & 0.76 \\
\hline $\begin{array}{l}\text { 4. I continue to work hard on projects even when } \\
\text { others do not support me. }\end{array}$ & $0.0 \%$ & $0.6 \%$ & $13.8 \%$ & $28.8 \%$ & $51.3 \%$ & 4.38 & 0.76 \\
\hline
\end{tabular}


Table 6: Percentage structure of the answers to the questions on entrepreneur's social skills

\begin{tabular}{|l|c|c|c|c|c|c|c|}
\hline \multicolumn{1}{|c|}{ Social skills } & $\mathbf{1}$ & $\mathbf{2}$ & $\mathbf{3}$ & $\mathbf{4}$ & $\mathbf{5}$ & $\mathbf{M}$ & SD \\
\hline 1. I can perceive other people well. & $0.0 \%$ & $5.0 \%$ & $24.4 \%$ & $38.8 \%$ & $26.3 \%$ & 3.91 & 0.86 \\
\hline $\begin{array}{l}\text { 2. I can estimate the right time to ask someone for } \\
\text { a favour. }\end{array}$ & $0.6 \%$ & $1.3 \%$ & $19.4 \%$ & $45.6 \%$ & $27.5 \%$ & 4.04 & 0.78 \\
\hline 3. I can adapt easily to any social situation. & $0.0 \%$ & $0.6 \%$ & $15.0 \%$ & $43.8 \%$ & $35.0 \%$ & 4.20 & 0.72 \\
\hline $\begin{array}{l}\text { 4. I can talk to any type of people (to people from } \\
\text { different backgrounds, age, or social status). }\end{array}$ & $0.0 \%$ & $1.9 \%$ & $6.3 \%$ & $26.3 \%$ & $60.0 \%$ & 4.53 & 0.71 \\
\hline
\end{tabular}

Table 7: Percentage structure of the answers to the questions on the interaction of the entrepreneurial team

\begin{tabular}{|c|c|c|c|c|c|c|c|}
\hline Interaction in the entrepreneurial team & 1 & 2 & 3 & 4 & 5 & M & SD \\
\hline $\begin{array}{l}\text { 1. Every founder is completely integrated in the } \\
\text { entrepreneurial team. }\end{array}$ & $5.6 \%$ & $5.0 \%$ & $21.9 \%$ & $22.5 \%$ & $39.4 \%$ & 3.90 & 1.18 \\
\hline $\begin{array}{l}\text { 2. Working in the entrepreneurial team represents } \\
\text { the highest priority for every team member (in } \\
\text { comparison with other activities or leisure time). }\end{array}$ & $3.1 \%$ & $3.8 \%$ & $25.6 \%$ & $38.1 \%$ & $23.8 \%$ & 3.80 & 0.97 \\
\hline $\begin{array}{l}\text { 3. Within the entrepreneurial team, tasks are well } \\
\text { coordinated, so the same jobs are not done twice. }\end{array}$ & $1.3 \%$ & $3.8 \%$ & $25.0 \%$ & $44.4 \%$ & $20.0 \%$ & 3.83 & 0.85 \\
\hline $\begin{array}{l}\text { 4. The communication between entrepreneurial } \\
\text { team members is excellent. }\end{array}$ & $0.6 \%$ & $2.5 \%$ & $20.0 \%$ & $41.9 \%$ & $29.4 \%$ & 4.03 & 0.83 \\
\hline $\begin{array}{l}\text { 5. I am satisfied with the accuracy of information } \\
\text { interchange within the entrepreneurial team. }\end{array}$ & $0.0 \%$ & $6.3 \%$ & $25.0 \%$ & $40.6 \%$ & $22.5 \%$ & 3.84 & 0.86 \\
\hline
\end{tabular}

Based on the answers to the questions about entrepreneur's knowledge, it can be concluded that the entrepreneurs had, on average, 14 years of work experience when they established their companies, one half of them having more than 10 years of work experience. They had on average 8 years of work experience in related business activities and 5 years of work experience in managerial positions at the time they founded their companies. One half of them have a university degree.

The entrepreneurs work 45 hours per week on average in their companies and one half of them work more than 50 hours per week. In more than one half of the companies, the initial capital comes exclusively from the entrepreneurs' personal savings.

Regarding the answers to the questions about entrepreneur's motivation, the majority of the respondents stated that the main reasons why they established a company are that they were not able to find a good job, they wanted to be independent and their own bosses and to put their personal ideas into practice. The question regarding the inability of finding a good job is the only question where 1 represents the highest performance and 5 the lowest performance. Bearing that in mind, these answers suggest that a certain number of the respondents did not read the questions carefully. As a result, the answers to the question about the inability of finding a good job had very low correlation with the answers to the other two questions. For that reason, the question about the inability of finding a good job was excluded from the analysis.

The answers to the other two questions were then loaded into one factor. However, it turned out that the individual Kaiser-Meyer-Olkin (KMO) statistics for one variable (question) was below the minimum acceptable value of 0.5 . In addition, the Cronbach's Alpha for the factor Motivation was 0.5 which indicates that those two questions are not reliable measures of entrepreneur's motivation. Consequently, all the questions about entrepreneur's motivation had to be excluded from further analysis.

The answers to the questions about tenacity, social skills, and the interaction within the entrepreneurial team suggest that a certain level of bias existed when the respondents were filling in the questionnaire. Most of them tended to evaluate their human capital slightly better than it actually was. In fact, in most cases the respondents chose numbers 4 (agree) or 5 (strongly agree). 
Besides the questions related to motivation, three more questions were excluded from further analysis because the answers to them had very low correlation with the answers to the other questions. These questions are: (1) How many hours per week do you work on average in your company, (2) What percentage of the company's initial capital comes from your personal savings, and (3) The level of your education on a scale of 1 to 5 .

After all those questions had been excluded, the sampling adequacy was tested using the KMO test. The KMO statistic was 0.744 which is, according to Field (2009, p. 647), regarded as good. All KMO values for individual items were also above the minimum acceptable value of 0.5 (the lowest value was 0.585). Based on that, it can be concluded that the sample is adequate for the analysis. Bartlett's test of sphericity ${ }^{2}(91)$ $=761.999, p=0.000$, indicated that the correlations between items were sufficiently large for factor analysis.

Factor analysis was performed and three factors were extracted. Table 8 shows eigenvalues of extracted factors and the percentage of variance explained by each factor.

Table 8: Eigenvalues and total variance explained

\begin{tabular}{|c|c|c|c|c|c|c|}
\hline \multirow{2}{*}{$\begin{array}{c}\text { Factor } \\
\text { (component) }\end{array}$} & \multicolumn{3}{|c|}{ After extraction } & \multicolumn{3}{c|}{ After rotation } \\
\cline { 2 - 7 } & Eigenvalues & \% of Variance & Cumulative \% & Eigenvalues & \% of Variance & Cumulative \% \\
\hline 1 & 4.018 & 28.70 & 28.70 & 3.202 & 22.87 & 22.87 \\
\hline 2 & 1.923 & 13.74 & 42.44 & 2.629 & 18.78 & 41.65 \\
\hline 3 & 1.825 & 13.03 & 55.47 & 1.934 & 13.81 & 55.47 \\
\hline
\end{tabular}

According to Kaiser's criterion, four factors should be extracted and by Jolliffe's criterion it was 6 factors. Kaiser's criterion suggests retaining all the factors with eigenvalues higher than 1 , while according to Jolliffe's criterion, the factors with eigenvalues higher than 0.7 should be retained (Field, 2009, pp. 640-641). By looking at the scree plot, which represents a graph of each eigenvalue (Y-axis) against the factor with which it is associated (X-axis), it can be seen that the curve has two points of inflexion. The first inflexion point occurs at the third factor and the second one at the fourth factor, which means that, according to this criterion, two or three factors should be extracted.

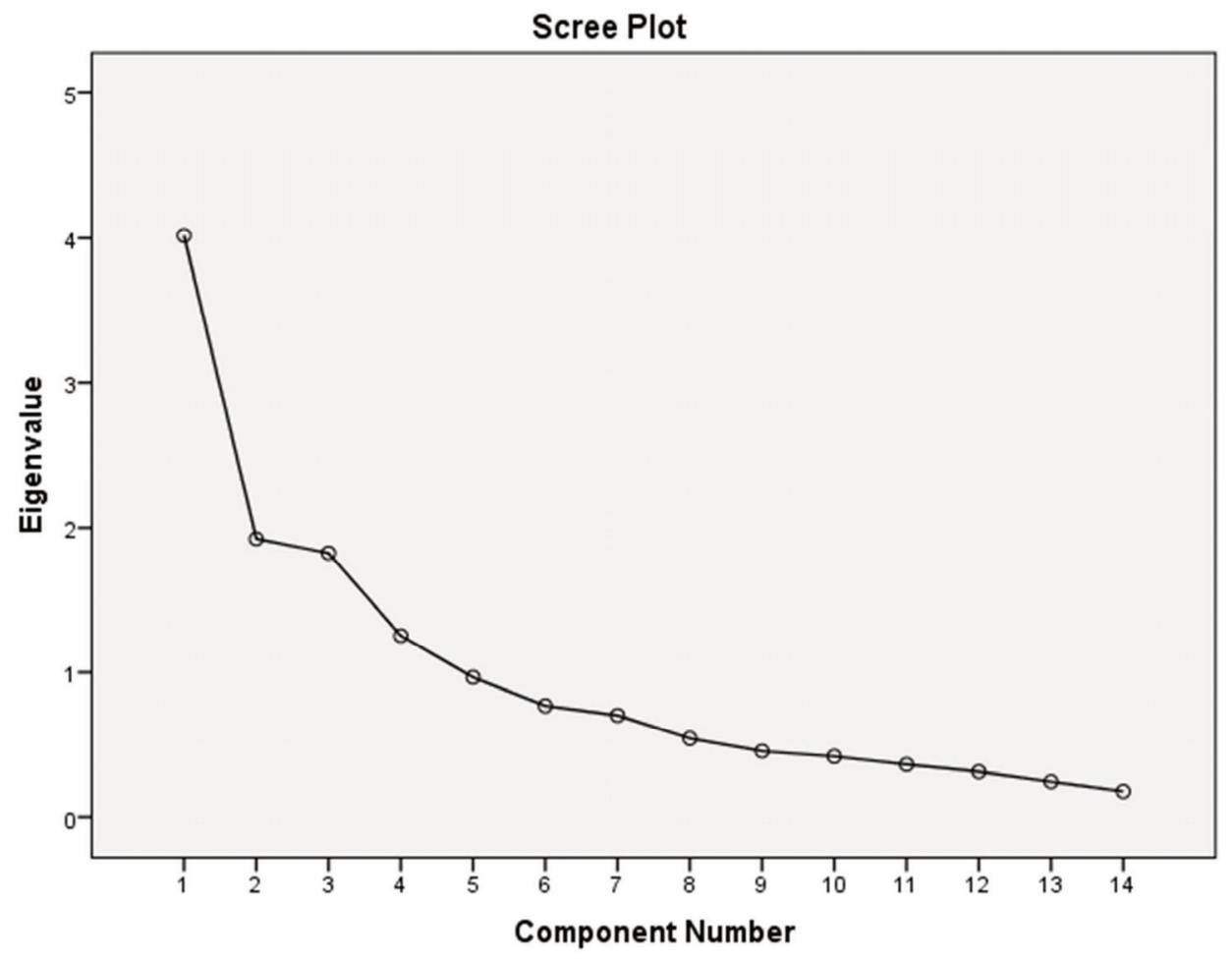

Figure 1: Scree plot 
When four factors were extracted based on Kaiser's criterion, it was difficult to identify common themes among the questions that were loaded into the same factor and label the factors. When more than four factors were extracted, the results were even worse. The questions were loaded into factors without any order. Therefore, the solution offered by scree plot was accepted and three factors were retained: (1) Interaction of the entrepreneurial team, (2) Social skills and tenacity, and (3) Knowledge of the entrepreneur. Those three factors in combination explain $55.47 \%$ of the variance.

As a rotation method, orthogonal rotation (Varimax) was used. Table 9 shows factor loadings larger than 0.4 for the extracted factors after rotation. The variables are listed in the order of the size of their factor loadings, so the structure of the retained factors can be seen clearly. The factor scores were calculated based on Anderson-Rubin method.

Table 9: Factor loadings after rotation

\begin{tabular}{|c|c|c|c|c|}
\hline Factors & Questions & 1 & 2 & 3 \\
\hline \multirow{5}{*}{$\begin{array}{l}\text { Interaction of the } \\
\text { entrepreneurial } \\
\text { team }\end{array}$} & $\begin{array}{l}\text { Tasks within the entrepreneurial team are well coordinated, so } \\
\text { the same jobs are not done twice. }\end{array}$ & \multirow{5}{*}{$\begin{array}{l}0.862 \\
0.837 \\
0.789\end{array}$} & & \\
\hline & $\begin{array}{l}\text { The communication between entrepreneurial team members } \\
\text { is excellent. }\end{array}$ & & & \\
\hline & $\begin{array}{l}\text { I am satisfied with the accuracy of information interchange } \\
\text { within the entrepreneurial team. }\end{array}$ & & & \\
\hline & $\begin{array}{l}\text { Working in the entrepreneurial team represents the highest } \\
\text { priority for every team member (in comparison with other } \\
\text { activities or leisure time). }\end{array}$ & & & \\
\hline & $\begin{array}{l}\text { Every founder is completely integrated in the entrepreneurial } \\
\text { team. }\end{array}$ & & & \\
\hline \multirow{6}{*}{$\begin{array}{l}\text { Social skills and } \\
\text { tenacity }\end{array}$} & I can estimate other people well. & & \multirow{6}{*}{$\begin{array}{l}0.756 \\
0.755 \\
0.700 \\
0.621 \\
0.537 \\
0.465\end{array}$} & \\
\hline & $\begin{array}{l}\text { I continue to work hard on projects even when others do not } \\
\text { support me. }\end{array}$ & & & \\
\hline & $\begin{array}{l}\text { I can think of many times when I persevered with work when } \\
\text { others have quit. }\end{array}$ & & & \\
\hline & I can estimate the right time to ask someone for a favour. & & & \\
\hline & I can adapt easily to any social situation. & & & \\
\hline & $\begin{array}{l}\text { I can talk to any type of people (to people from different } \\
\text { backgrounds, age or social status). }\end{array}$ & & & \\
\hline \multirow{3}{*}{$\begin{array}{l}\text { Knowledge of the } \\
\text { entrepreneur }\end{array}$} & $\begin{array}{l}\text { How many years of work experience did you have when you } \\
\text { established your company? }\end{array}$ & & & 0.800 \\
\hline & $\begin{array}{l}\text { How many years of work experience in related business } \\
\text { activities did you have when you established your company? }\end{array}$ & & & 0.790 \\
\hline & $\begin{array}{l}\text { How many years of work experience in managerial positions } \\
\text { did you have when you established your company? }\end{array}$ & & & 0.758 \\
\hline
\end{tabular}

All three factors have high reliabilities. Cronbach's Alpha is higher than 0.7 for each factor, which is considered acceptable. Based on that, it can be concluded that the interaction within the entrepreneurial team, the social skills, and tenacity and knowledge of the entrepreneur are reliable measures of human capital.

Table 10: Cronbach's Alpha

\begin{tabular}{|l|c|}
\hline \multicolumn{1}{|c|}{ Factors } & Cronbach's Alpha \\
\hline Interaction in the entrepreneurial team & 0.826 \\
\hline Social skills and tenacity & 0.746 \\
\hline Knowledge of the entrepreneur & 0.704 \\
\hline
\end{tabular}




\subsection{Multiple regression analysis}

Table 11 shows the results of the multiple regression analysis in which dependent variable is ROA. P-values are shown in parentheses below the coefficient estimates. The results that are significant at the $10 \%$ level are bolded.

Table 11: The impact of human capital on ROA

\begin{tabular}{|lccccc|}
\hline \multicolumn{1}{|c}{ ROA } & Model 1 & Model 2 & Model 3 & Model 4 & Model 5 \\
\hline Human capital & & & & & \\
\hline Interaction in the team & & 0.0379 & $\mathbf{0 . 0 3 1 0}$ & 0.0164 & $\mathbf{0 . 0 2 4 0}$ \\
Social skills and tenacity & & $(0.134)$ & $\mathbf{( 0 . 0 5 0 )}$ & $(0.328)$ & $\mathbf{( 0 . 0 5 8 )}$ \\
& & 0.0125 & $\mathbf{0 . 0 3 1 3}$ & 0.0108 & $\mathbf{0 . 0 1 7 9}$ \\
Knowledge of the entrepreneur & & $(0.577)$ & $\mathbf{( 0 . 0 3 1 )}$ & $(0.496)$ & $\mathbf{( 0 . 0 7 8 )}$ \\
& & 0.0215 & 0.0089 & 0.0236 & 0.0147 \\
Control variables & & $(0.285)$ & $(0.557)$ & $(0.227)$ & $(0.374)$ \\
\hline Number of employees & & & & & \\
& $\mathbf{0 . 0 0 0 6}$ & $\mathbf{0 . 0 0 2 3}$ & 0.0003 & $\mathbf{0 . 0 0 0 5}$ & 0.0002 \\
Trade & $\mathbf{( 0 . 0 3 3 )}$ & $\mathbf{( 0 . 0 6 1 )}$ & $(0.899)$ & $\mathbf{( 0 . 0 7 0 )}$ & $(0.771)$ \\
& 0.0041 & -0.0078 & -0.0067 & -0.0001 & -0.0008 \\
Services related to mfg. & $(0.659)$ & $(0.857)$ & $(0.862)$ & $(0.992)$ & $(0.931)$ \\
& $\mathbf{0 . 0 7 3 5}$ & $\mathbf{0 . 3 1 2 1}$ & $\mathbf{0 . 3 4 2 1}$ & $\mathbf{0 . 0 7 0 8}$ & $\mathbf{0 . 0 7 2 2}$ \\
Other services & $\mathbf{( 0 . 0 0 0 )}$ & $\mathbf{( 0 . 0 0 0 )}$ & $\mathbf{( 0 . 0 0 0 )}$ & $\mathbf{( 0 . 0 0 0 )}$ & $\mathbf{( 0 . 0 0 0 )}$ \\
& 0.0201 & 0.0762 & 0.0627 & 0.0171 & 0.0174 \\
Constant & $(0.183)$ & $(0.241)$ & $(0.194)$ & $(0.234)$ & $(0.168)$ \\
& 1.4107 & 0.1147 & 0.1276 & 1.3447 & 1.3399 \\
& $(0.000)$ & $(0.001)$ & $(0.000)$ & $(0.000)$ & $(0.000)$ \\
\hline F statistic & $\mathbf{8 . 2 5}$ & $\mathbf{4 . 9 4}$ & $\mathbf{4 . 6 5}$ & $\mathbf{4 . 9 9}$ & $\mathbf{4 . 8 7}$ \\
Prob > F & $\mathbf{( 0 . 0 0 0 )}$ & $\mathbf{( 0 . 0 0 0 )}$ & $\mathbf{( 0 . 0 0 0 )}$ & $\mathbf{( 0 . 0 0 0 )}$ & $\mathbf{( 0 . 0 0 0 )}$ \\
\hline R-squared & $\mathbf{0 . 2 2 1 5}$ & 0.2366 & 0.1855 & 0.2361 & 0.1926 \\
Adj R-squared & $/$ & $/$ & 0.1456 & $/$ & $\mathbf{0 . 1 5 3 0}$ \\
\hline Number of observations & 151 & 151 & 151 & 151 & 151 \\
\hline
\end{tabular}

In models 1, 2 and 4, the Ordinary least squares (OLS) method with heteroscedasticity-robust standard errors was used. In all three models heteroscedasticity was found, therefore, standard errors had to be corrected. In models 3 and 5, the Feasible generalized least squares (FGLS) method was used. According to Wooldridge (2016, p. 260), the FGLS estimator is not unbiased, but it is consistent and asymptotically more efficient in comparison with OLS.

Model 1 contains only control variables as independent variables. A dependent variable is the natural logarithm of the ROA. Since some companies had negative ROAs and the log cannot be used if a variable takes zero or negative values, a constant was added to all variables before the ROA was transformed. Variables number of employees $(p=0.033)$ and services related to manufacturing $(p=0.000)$ are statistically significant. The companies with more employees have a slightly higher ROA than the companies with fewer employees. The companies that provide services related to manufacturing have a $7.35 \%$ higher ROA on average in comparison with manufacturing companies with the same number of employees. There is no significant difference in terms of the ROA between manufacturing companies, trade companies and companies that provide other services with the same number of employees. Control variables together explain about $22.15 \%$ of the variation in the ROA in the sample.

Model 2 contains the elements of human capital and control variables as independent variables. The dependent variable is the ROA. In this model, none of the variables that represent the elements of human capital is statistically significant. Independent variables together explain about $23.66 \%$ of the variation in the ROA in the sample.

Model 3 contains the elements of human capital and control variables as independent variables. Dependent variable is also the ROA, and the FGLS method was used in this model. Variables interaction of the entrepreneurial team $(p=0.050)$ and social skills and tenacity $(p=0.031)$, as the elements of human capital, are statistically significant and have a positive impact on the ROA. The magnitude of the impact cannot be estimated because the model indicates how much the ROA will increase if an element of human capital increases by 1 , which is difficult to interpret. Nonetheless, a positive impact of human capital on the ROA is indisputable. Independent variables together explain about $14.56 \%$ of the variation in the ROA. 
Model 4 contains the elements of human capital and control variables as independent variables. In this model, the elements of human capital and the ROA, as dependent variable, are ina logarithmic form. None of the variables that represent the elements of human capital is statistically significant. Independent variables together explain about $23.61 \%$ of the variation in the ROA.

Model 5 contains the elements of human capital and control variables as independent variables. The elements of human capital and the ROA are in logarithmic form, and the FGLS method was used in this model. Variables interaction of the entrepreneurial team $(p=0.058)$ and social skills and tenacity $(p=0.078)$, as the elements of human capital, are statistically significant and have a positive impact on the ROA. More precisely, the improvement inf the interaction within the entrepreneurial team by $10 \%$ leads to the increase in the ROA by $0.24 \%$. The improvement of social skills and increasing tenacity by $10 \%$ leads to the increase in the ROA by $0.179 \%$. Independent variables together explain about $15.3 \%$ of the variation in the ROA.

The companies were divided into four groups depending on the magnitude of their ROA, as shown in Table 12 , while using ordered probit model. In this model, the dependent variable takes the value of 0 if a company is in the first group, 1 if a company is in the second group, 2 if a company is in the third group, or 3 if a company is in the fourth group. Independent variables are the elements of human capital. Independent variables and control variables are in a logarithmic form.

Table 12: Companies divided into four groups

\begin{tabular}{|l|c|c|}
\hline \multicolumn{1}{|c|}{ ROA } & Frequency & Percentage \\
\hline 1. Less than 3\% & 30 & $20 \%$ \\
\hline 2. Between 3\% and 8\% & 34 & $23 \%$ \\
\hline 3. Between 8\% and 30\% & 48 & $32 \%$ \\
\hline 4. More than 30\% & 39 & $26 \%$ \\
\hline Total & 151 & $100 \%$ \\
\hline
\end{tabular}

Table 13 shows the results based on the maximum log likelihood method. In the first column, coefficient estimates and p-values (in parentheses) are presented. In the second and third columns, marginal effects calculated for the mean values in the sample are shown. The results that are significant at the $10 \%$ level are bolded.

Table 13: The impact of human capital on ROA

\begin{tabular}{|c|c|c|c|}
\hline \multirow{2}{*}{ ROA } & \multirow{2}{*}{ OPROBIT } & \multicolumn{2}{|c|}{ Marginal effects } \\
\hline & & First outcome & Last outcome \\
\hline \multicolumn{4}{|l|}{ Human capital } \\
\hline \multirow[t]{2}{*}{ Interaction in the team } & 0.3178 & -0.0794 & 0.0969 \\
\hline & $(0.220)$ & & \\
\hline \multirow[t]{2}{*}{ Social skills and tenacity } & 0.4053 & -0.1013 & 0.1235 \\
\hline & $(0.213)$ & & \\
\hline \multirow[t]{2}{*}{ Knowledge of the entrepreneur } & 0.6818 & -0.1704 & 0.2078 \\
\hline & $(0.073)$ & & \\
\hline \multicolumn{4}{|l|}{ Control variables } \\
\hline \multirow[t]{2}{*}{ Number of employees } & -0.1996 & 0.0499 & -0.0608 \\
\hline & $(0.415)$ & & \\
\hline \multirow[t]{2}{*}{ Trade } & -0.0131 & 0.0033 & -0.0040 \\
\hline & $(0.954)$ & & \\
\hline \multirow[t]{2}{*}{ Services related to $\mathrm{mfg}$. } & 1.1547 & -0.2232 & 0.3940 \\
\hline & $(0.000)$ & & \\
\hline \multirow[t]{2}{*}{ Other services } & 0.2959 & -0.0666 & 0.0966 \\
\hline & $(0.282)$ & & \\
\hline \multirow[t]{2}{*}{ Cut 1} & 0.8253 & & \\
\hline & $(0.369)$ & & \\
\hline \multirow[t]{2}{*}{ Cut 2} & 1.5626 & & \\
\hline & $(0.088)$ & & \\
\hline \multirow[t]{2}{*}{ Cut 3} & 2.5261 & & \\
\hline & $(0.006)$ & & \\
\hline Wald chi2(7) & 32.94 & & \\
\hline Prob > chi2 & $(0.000)$ & & \\
\hline Pseudo R2 & 0.0857 & & \\
\hline Number of observations & 151 & & \\
\hline
\end{tabular}


Since the companies are divided into four groups, the model has three cut off points which separate the groups. The second $(p=0.088)$ and the third $(p=0.006)$ cut off points are statistically significant, indicating that the way the companies are divided into groups is appropriate.

The variables knowledge of the entrepreneur $(p=0.073)$ and services related to manufacturing $(p=0.000)$ are statistically significant. Knowledge of the entrepreneur as the element of human capital has a positive impact on the ROA. The entrepreneurs with vast knowledge have better chances that their company falls into the group with a higher ROA.

In this model, the sign of the coefficient estimate can be interpreted, not the magnitude. It can only be inferred whether the impact is positive or negative. However, based on marginal effects, it can be concluded that the entrepreneurs who improve their knowledge by $10 \%$ have $1.704 \%$ less chance that their company falls into the first group and $2.078 \%$ more chance that their company falls into the fourth group. The entrepreneurs who improve their knowledge by $50 \%$ have $8.52 \%$ less chance that their company falls into the first group and $10.39 \%$ more chance that their company falls into the fourth group. The first group consists of the companies whose ROA was lower than $3 \%$, while the fourth group consists of the companies whose ROA was higher than $30 \%$.

Table 14 displays the results of a multiple regression analysis in which the dependent variable is sales revenue. P-values are shown in parentheses below the coefficient estimates. The results that are significant at the $10 \%$ level are bolded.

Table 14: The impact of human capital on sales revenue

\begin{tabular}{|c|c|c|c|c|c|}
\hline Sales revenue & Model 1 & Model 2 & Model 3 & Model 4 & Model 5 \\
\hline \multicolumn{6}{|l|}{ Human capital } \\
\hline \multirow[t]{2}{*}{ Interaction in the team } & & 7.8845 & 2.5812 & 0.3259 & 0.1897 \\
\hline & & $(0.117)$ & $(0.392)$ & $(0.079)$ & $(0.094)$ \\
\hline \multirow[t]{2}{*}{ Social skills and tenacity } & & -1.5473 & 1.0712 & 0.0752 & -0.0114 \\
\hline & & $(0.707)$ & $(0.726)$ & $(0.776)$ & $(0.964)$ \\
\hline \multirow[t]{2}{*}{ Knowledge of the entrepreneur } & & 7.2424 & -1.3007 & 0.2217 & -0.2014 \\
\hline & & $(0.339)$ & $(0.704)$ & $(0.478)$ & $(0.400)$ \\
\hline \multicolumn{6}{|l|}{ Control variables } \\
\hline \multirow[t]{2}{*}{ Number of employees } & 0.0304 & 3.3765 & 3.2019 & 0.0299 & 0.0453 \\
\hline & $(0.000)$ & $(0.000)$ & $(0.000)$ & $(0.000)$ & $(0.000)$ \\
\hline \multirow[t]{2}{*}{ Trade } & 0.2879 & 27.3710 & 23.058 & 0.2169 & 0.2784 \\
\hline & (0.168) & $(0.220)$ & $(0.144)$ & $(0.320)$ & $(0.235)$ \\
\hline \multirow[t]{2}{*}{ Services related to $\mathrm{mfg}$. } & -0.3823 & -19.901 & -11.970 & -0.4312 & -0.4322 \\
\hline & $(0.028)$ & $(0.098)$ & $(0.141)$ & $(0.018)$ & $(0.006)$ \\
\hline \multirow[t]{2}{*}{ Other services } & -0.5345 & -28.961 & -16.127 & -0.5740 & -0.4786 \\
\hline & $(0.007)$ & $(0.023)$ & $(0.118)$ & $(0.005)$ & $(0.018)$ \\
\hline \multirow[t]{2}{*}{ Constant } & 3.2723 & 23.466 & 18.169 & 2.4729 & 3.2094 \\
\hline & $(0.000)$ & $(0.062)$ & $(0.053)$ & $(0.000)$ & $(0.000)$ \\
\hline F statistic & 8.23 & 3.82 & 3.77 & 4.93 & 6.90 \\
\hline Prob $>\mathrm{F}$ & $(0.000)$ & $(0.001)$ & $(0.001)$ & $(0.000)$ & $(0.000)$ \\
\hline R-squared & 0.2331 & 0.3341 & 0.1556 & 0.2475 & 0.2524 \\
\hline Adj R-squared & 1 & 1 & 0.1143 & 1 & 0.2158 \\
\hline Number of observations & 151 & 151 & 151 & 151 & 151 \\
\hline
\end{tabular}

In models 1, 2 and 4, the OLS method with heteroscedasticity-robust standard errors was used. In all three models heteroscedasticity was found, so standard errors had to be corrected. In models 3 and 5, the FGLS method was used. 
Model 1 contains only control variables as independent variables. The dependent variable is the natural logarithm of sales revenue. Variables: the number of employees $(p=0.000)$, the services related to manufacturing $(p=0.028)$ and other services $(p=0.007)$ are statistically significant. The companies with more employees have higher sales revenue than the companies with fewer employees, which is expected and obvious. Employing an additional worker on average increases sales revenue by $3.04 \%$. The companies that provide services related to manufacturing have a $38.23 \%$ lower sales revenue on average in comparison with manufacturing companies with the same number of employees. The companies that provide other services have a $53.45 \%$ lower sales revenue on average in comparison with manufacturing companies with the same number of employees. Between manufacturing and trade companies with the same number of employees there is no significant difference in terms of sales revenue. All the control variables explain about $23.31 \%$ of the variation in the sales revenue in the sample.

Model 2 contains the elements of human capital and control variables as independent variables. The dependent variable is sales revenue. None of the variables that represent the elements of human capital is statistically significant in this model. All the independent variables explain about $33.41 \%$ of the variation in the sales revenue in the sample.

Model 3 contains the elements of human capital and control variables as independent variables. The dependent variable is also the sales revenue, and the model FGLS method was used. None of the variables that represent the elements of human capital is statistically significant. All the independent variables explain about $11.43 \%$ of the variation in the sales revenue.

Model 4 contains the elements of human capital and control variables as independent variables. In this model, the elements of human capital and sales revenue, as dependent variable, are in logarithmic form. Variable interaction of the entrepreneurial team $(p=0.079)$, as the element of human capital, is statistically significant and has a positive impact on the sales revenue. More precisely, the improvement of entrepreneurial team's interaction by $10 \%$ leads to the increase in the sales revenue by $3.259 \%$. All the independent variables explain about $24.75 \%$ of the variation in the sales revenue.

Model 5 contains the elements of human capital and control variables as independent variables. The elements of human capital and sales revenue are in a logarithmic form, and the FGLS method was used. Variable interaction within the entrepreneurial team $(p=0.094)$, as the element of human capital, is statistically significant and has a positive impact on the sales revenue. The improvement in the entrepreneurial team's interaction by $10 \%$ leads to an increase in the sales revenue by $1.897 \%$. Compared to the previous model, this model also reveals the positive impact of human capital on the sales revenue, but the magnitude of the impact is slightly lower. All the independent variables explain about $21.58 \%$ of the variation in the sales revenue.

The companies were divided into three groups depending on the size of their sales revenue, as shown in Table 15, while using the ordered probit model. In this model, the dependent variable takes value of 0 if a company is in the first group, 1 if a company is in the second group, or 2 if a company is in the third group. Independent variables are the elements of human capital and control variables, and they are in a logarithmic form.

Table 15: Companies divided into three groups

\begin{tabular}{|l|c|c|}
\hline \multicolumn{1}{|c|}{ Sales revenue } & Frequency & Percentage \\
\hline 1. Less than 10 million RSD & 36 & $24 \%$ \\
\hline 2. Between 10 and 50 million RSD & 74 & $49 \%$ \\
\hline 3. More than 50 million RSD & 41 & $27 \%$ \\
\hline Total & 151 & $100 \%$ \\
\hline
\end{tabular}

Table 16 shows the results based on the maximum log likelihood method. In the first column coefficient estimates and p-values (in parentheses) are shown. In the second and third columns, marginal effects calculated for the mean values in the sample are displayed. The results that are significant at the $10 \%$ level are bolded. 
Table 16: The impact of human capital on sales revenue

\begin{tabular}{|c|c|c|c|}
\hline \multirow{2}{*}{ Sales revenue } & \multirow{2}{*}{ OPROBIT } & \multicolumn{2}{|c|}{ Marginal effects } \\
\hline & & First outcome & Last outcome \\
\hline \multicolumn{4}{|l|}{ Human capital } \\
\hline Interaction of the team & $\begin{array}{l}0.2286 \\
(0.304)\end{array}$ & -0.0643 & 0.0717 \\
\hline Social skills and tenacity & $\begin{array}{c}-0.0059 \\
(0.987)\end{array}$ & 0.0017 & -0.0019 \\
\hline Knowledge of the entrepreneur & $\begin{array}{c}0.006 \\
(0.988) \\
\end{array}$ & -0.0016 & 0.0018 \\
\hline \multicolumn{4}{|l|}{ Control variables } \\
\hline Number of employees & $\begin{array}{l}1.1873 \\
(0.000)\end{array}$ & -0.3340 & 0.3723 \\
\hline Trade & $\begin{array}{l}0.5510 \\
(0.064)\end{array}$ & -0.1368 & 0.1866 \\
\hline Services related to $\mathrm{mfg}$. & $\begin{array}{l}-0.2671 \\
(0.238)\end{array}$ & 0.0787 & -0.0801 \\
\hline Other services & $\begin{array}{l}-0.6571 \\
(0.020)\end{array}$ & 0.2155 & -0.1708 \\
\hline Cut 1 & $\begin{array}{l}2.2309 \\
(0.033)\end{array}$ & & \\
\hline Cut 2 & $\begin{array}{l}3.7608 \\
(0.000)\end{array}$ & & \\
\hline $\begin{array}{l}\text { Wald chi2(7) } \\
\text { Prob > chi2 }\end{array}$ & $\begin{array}{c}27.58 \\
(0.000)\end{array}$ & & \\
\hline Pseudo R2 & 0.1117 & & \\
\hline
\end{tabular}

Since the companies are divided into three groups, the model has two cut off points which separate the groups. Both cut off points are statistically significant, indicating that the way the companies are divided into groups is appropriate. However, none of the variables that represent the elements of human capital is statistically significant in this model.

The first hypothesis states that entrepreneurial firms that have a larger human capital tend to have a higher ROA. It was found that the elements of human capital, such as the interaction within the entrepreneurial team, social skills and tenacity and knowledge of the entrepreneur, have a positive impact on the ROA. Based on that, it can be concluded that the first hypothesis has been confirmed.

The second hypothesis states that entrepreneurial firms that have a larger human capital tend to have higher sales revenue. It can be concluded that the interaction of the entrepreneurial team, as the element of human capital, has a positive impact on the sales revenue. Social skills and tenacity, and the knowledge of the entrepreneur do not have an impact on the sales revenue. Based on that, it can be concluded that the second hypothesis has been partially confirmed.

\section{Conslusion}

This paper examines the influence of human capital on financial performance of entrepreneurial firms in Serbia. It makes a valuable contribution to the literature since the results of this study are comparable with the results of similar studies about the relationship between human capital (and more generally intellectual capital) and entrepreneurial firms' performance. As shown by Simic \& Slavkovic (2019) and Simic \& Ognjanovic (2019), the results indicate that human capital has a positive impact on financial performance of Serbian entrepreneurial firms. These results are also consistent with the results of similar studies that were conducted for other countries. For example, Pena (2002) have shown that human capital of the entrepreneur, organizational capital, and relational capital are important intangible assets that are related positively to venture performance in Spain. Hormiga et al. (2011) have pointed out that human and relational capital play an important role in the development of new companies registered in the Canary Islands. Based on the results of a case study that included 
three Bulgarian entrepreneurial firms, Petrova Galabova (2014) concludes that human capital is the most widely acknowledged capital compared to structural and relational capital. Khan at al. (2019) conclude that the knowledge, skills and educational level of the entrepreneur, entrepreneurial opportunities, connections with other entrepreneurs and business angels have a significant and positive impact on venture creation decisions in India. Matricano (2016) indicates that human, structural and relational capital affected start-up expectations in Italy. Unger et al. (2011) analysed the results of 70 research studies that were undertaken for various countries and concluded that there was a certain, yet significant relationship between human capital and entrepreneurial success.

The paper can help entrepreneurs and company founders, as well as economic and development policy makers, to better understand the importance of human capital for improving financial and overall business performance of newly created ventures. Entrepreneurs and policy makers should pay special attention to those elements of human capital that turned out to have a significant impact on the ROA and the sales revenue.

The research has several limitations. The first limitation relates to a relatively small number of companies that participated in the study. Out of 1,559 companies that were included in the sample, only 151 were analysed. The response rate was relatively low and some companies had to be excluded because the questionnaires that were received from them were incomplete. The second limitation relates to the fact that the conclusions of this research were made by using a reduced amount of data. When the questions were loaded into factors some information was discarded. In multiple regression analysis three factors that represent the elements of human capital were used as independent variables. Those three factors in combination explain only $55.45 \%$ of the variance. The third limitation relates to data reliability. In the literature, the ROE is often used as a performance indicator, but in this research the ROE could not be used because the data necessary for its calculation turned out to be unreliable. The problems related to the reliability of financial statements were partially eliminated by using sales revenue as a performance indicator since its amount is difficult to present falsely. Finally, the fourth limitation relates to objectivity of the entrepreneurs and their tendency to evaluate their human capital slightly better than it actually is, which could be noticed from their answers.

Future research on this topic can focus on the impact of intellectual capital on the business performance of entrepreneurial firms. Instead of focusing only on human capital, future research may choose to focus on all three components of intellectual capital; such as human, structural, and relational capital. In addition, future research can analyse the impact of intellectual capital not only on the firms' financial performance, but also on the firms' market and operational performance. Moreover, future research can include not only Serbia, but also some other countries, such as West Balkan countries or former Yugoslavian states. In future research structural equation modelling (SEM) can also be used. Finally, instead of using this methodology, they can be based on a case study. In that way most problems related to the lack of objectivity and different perceptions of the respondents can be eliminated. However, the sample will have to be smaller because a researcher will have to visit each company and organize interviews with the owners.

\section{REFERENCES}

[1] Baron, R. A., \& Markman, G. D. (2003). Beyond social capital: The role of entrepreneurs' social competence in their financial success. Journal of Business Venturing, 18(1), 41-60. DOI: 10.1016/S08839026(00)00069-0

[2] Baum, J. R., \& Locke, E. A. (2004). The relationship of entrepreneurial traits, skill, and motivation to subsequent venture growth. Journal of Applied Psychology, 89(4), 587-598. DOI: 10.1037/0021-9010.89.4.587

[3] Bontis, N., Janosevic, S., \& Dzenopoljac, V. (2013). Intellectual capital and the corporate performance of Serbian banks. Actuals Problems of Economics, 4 (142), 287-299.

[4] Bontis, N., Janosevic, S., \& Dzenopoljac, V. (2015). Intellectual capital in Serbia's hotel industry. International Journal of Contemporary Hospitality Management, 27(6), 1365 -1384. DOI: 10.1108/IJCHM-12-2013-0541

[5] Choong, K. K. (2008). Intellectual capital: Definitions, categorization, and reporting models. Journal of Intellectual Capital, 9(4), 609-638. DOI: 10.1108/14691930810913186

[6] Cokorilo, N., Nikolic, S., Milosevic, S., Trajkovic, M., \& Djuric, S. (2018). Start-up u Srbiji- Trendovi i strukturna analiza. The Ministry of Economy of the Republic of Serbia.

[7] Djekic, I. (2015). Improving human capital in Serbia. Ekonomika, 61(3), 133-150. DOI: 10.5937/ekonomika1503133D

[8] Dzenopoljac, V., Janosevic, S., \& Bontis, N. (2016). Intellectual capital and financial performance in the Serbian ICT industry. Journal of Intellectual Capital, 17(2), 373-396. DOI: 10.1108/JIC-07-2015-0068

[9] Eurostat. (2008). Statistical classification of economic activities in the European Community- NACE Rev. 2. Author. Retrieved from: https://ec.europa.eu/eurostat/documents/3859598/5902521/KS-RA-07-015-EN.PDF

[10] Field, A. (2009). Discovering statistics using SPSS (3rd ed.). SAGE Publications Ltd.

[11] Global Entrepreneurship Monitor (2018). Global report 2017/18. Author. Retrieved from: https://www.gemconsortium.org/file/open?fileld $=50012$ 
[12] Hormiga, E., Batista-Canino, R.M., \& Sanchez-Medina, A. (2011). The role of intellectual capital in the success of new ventures. International Entrepreneurship and Management Journal, 7(1), 71-92. DOI: 10.1007/s11365-010-0139-y

[13] Janosevic, S., \& Dzenopoljac, V. (2012). An investigation of intellectual capital influence on financial performance of top Serbian exporters. Ekonomika Preduzeca, november-december, 329-342. DOI: 10.5937/ekopre1208329J

[14] Janosevic, S., \& Dzenopoljac, V. (2015). The impact of intellectual capital on companies' market value and financial performance. Ekonomika Preduzeca, november-december, 354-371. DOI: 10.5937/ekopre1508354J

[15] Janosevic, S., \& Dzenopoljac, V. (2016). Inovativnost kao komponenta intelektualnog kapitala. In V. Marinkovic, V. Janjic \& V. Micic (Eds), Unapredenje konkurentnosti privrede republike Srbije (pp. 187203). University of Kragujevac, Faculty of Economics.

[16] Janosevic, S., Dzenopoljac, V., \& Bontis, N. (2013). Intellectual capital and financial performance in Serbia, Knowledge and Process Management, 20 (1), 1-11. DOI: 10.1002/kpm.1404

[17] Khan, A.M., Arafat, M.Y., Raushan, M.A., Saleem, I., Khan, N.A., \& Khan. M.M. (2019). Does intellectual capital affect the venture creation decision in India?. Journal of Innovation and Entrepreneurship, 8(10), 1-15.

[18] Komnenic, B., \& Pokrajcic, D. (2012). Intellectual capital and corporate performance of MNCs in Serbia. Journal of Intellectual Capital, 13(1), 106-119. DOI: 10.1108/14691931211196231

[19] Komnenic, B., Tomic, R., \& Pokrajcic, D. (2011). Intellectual capital as a valuable driver of corporate performance: Empirical research on the banking sector in Serbia. International Journal of Arts \& Sciences, 4(09), 283-298.

[20] Lechler, T. (2001). Social interaction: A determinant of entrepreneurial team venture success. Small Business Economics, 16(4), pp. 263-278. DOI: 10.1023/A:1011167519304

[21] Matricano, D. (2016). The impact of intellectual capital on start-up expectations. Journal of Intellectual Capital, 17(4), 654-674. DOI: 10.1108/JIC-04-2016-0040

[22] Measuring Intangibles to Understand and Improve Innovation Management - MERITUM (2002). Guidelines for Managing and Reporting on Intangibles. Author.

[23] Ocean Tomo. (2017). Components of S\&P 500 market value. Retrieved from: http://www.oceantomo.com/intangible-asset-market-value-study/

[24] OECD (2011). New sources of growth: Intangible assets. Author. Retrieved from: http://www.oecd.org/science/inno/46349020.pdf

[25] Pena, I. (2002). Intellectual capital and business start-up success. Journal of Intellectual Capital, 3(2), 180-198. DOI: 10.1108/14691930210424761

[26] Petrova Galabova, L. (2014). Recognition and management of intangibles by Bulgarian entrepreneurial firms. Journal of Intellectual Capital, 15(3), 376-391. DOI: 10.1108/JIC-05-2014-0056

[27] Ramos-Rodriguez, A-R., Medina-Garrido, J-A., Lorenzo-Gomez, J-D., \& Ruiz-Navarro, J. (2010). What you know or who you know? The role of intellectual and social capital in opportunity recognition. International Small Business Journal, 28(6), 566-582. DOI: 10.1177/0266242610369753

[28] Simic, M., \& Ognjanovic, J. (2019). Human capital efficiency and competitiveness of leading entrepreneurial firms. In B. Krstic (Ed.), Improving enterprise competitiveness (pp. 19-50). University Of Nis, Faculty of Economics.

[29] Simic, M., \& Slavkovic, M. (2019). The role of human capital in entrepreneurial innovativeness: Evidence from Serbia. Facta Universitatis, Series: Economics and Organization, 16(1), 49-58. DOI: 10.22190/FUEO1901049S

[30] Tovstiga, G. \& Tulugurova, E. (2007). Intellectual capital practices and performance in Russian enterprises. Journal of Intellectual Capital, 8(4), 695-707. DOI: 10.1108/14691930710830846

[31] Ugalde-Blinda, N., Balbastre-Benavent, F., Canet-Giner, T., \& Escriba-Carda, N. (2014). The role of intellectual capital and entrepreneurial characteristics as innovation drivers. Innovar, 24(53), 41-60. DOI: 10.15446/innovar.v24n53.43793

[32] Unger, J.M., Rauch, A., Frese, M., \& Rosenbusch, N. (2011). Human capital and entrepreneurial success: A meta-analytical review. Journal of Business Venturing, 26 (3), 341-358. DOI: 10.1016/j.jbusvent.2009.09.004

[33] World Economic Forum. (2017). The Global Competitiveness Report 2017-2018. Author. Retrieved from: http://www3.weforum.org/docs/GCR720172018/05FullReport/TheGlobalCompetitivenessReport2017\%E2\%80\%932018.pdf

[34] Wooldridge, J. (2016). Introductory econometrics: A modern approach (6th ed). Cengage Learning.

[35] Zeghal, D., \& Maaloul, A. (2010). Analysing value added as an indicator of intellectual apital and its consequences on company performance. Journal of Intellectual Capital, 11(1), 9-60. DOI: $10.1108 / 14691931011013325$

Received: 2020-02-24

Revisions requested: 2020-04-25

Revised: 2020-05-06 (two revisions)

Accepted: 2020-06-08 


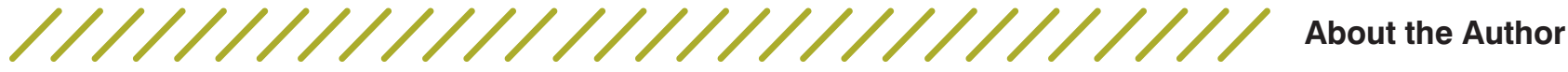

Mihailo Paunović

University of Belgrade, Faculty of Technology and Metallurgy, Serbia mpaunovic@tmf.bg.ac.rs

Mihailo Paunović is a Teaching and Research Assistant at the Faculty of Technology and Metallurgy, University of Belgrade. He teaches courses in Engineering Economics and

Enterprise Economics and Management at undergraduate studies. He is a PhD candidate at the Faculty of Economics, University of Belgrade. He holds a MSc in Accounting, Auditing and Corporate Finance from the Faculty of Economics, University of Belgrade and an International MSc in Business Administration with the specialization in Financial Management from Tias School for Business and Society, Tilburg University. 